\title{
Conflict Management Styles in the Workplace: A Study of First Generation Arab Muslim Immigrants in the United States
}

\author{
Jamil Al Wekhian ${ }^{1}$ \\ ${ }^{1}$ Department of Peace Studies, University of Missouri-Columbia, USA \\ Correspondence: Jamil Al Wekhian, International Conflict Management, Kennesaw State University, Atlanta, \\ GA, USA; Department of Peace Studies, University of Missouri-Columbia, Missouri, USA. Tel: 330-881-9084. \\ E-mail: jalwekhian@yahoo.com
}

Received: July 24, 2015

doi:10.5539/ijbm.v10n11p24
Accepted: August 27, $2015 \quad$ Online Published: October 28, 2015

URL: http://dx.doi.org/10.5539/ijbm.v10n11p24

\begin{abstract}
Multiple studies have shown that culture, religiosity, and gender influence people's behavior in managing their conflict; however, there has been little investigation of the impact of the acculturation process on these variables utilized by first generation Arab Muslim immigrants in the United States. My study follows a sequential explanatory model with a mixed methods approach, and specifically explores the conflict management styles utilized by first generation Arab Muslim immigrants in the U.S. and how their culture, gender, and religiosity contribute to these processes. Data was collected by conducting 145 online surveys and 12 face-to-face semi-structured interviews, with the sample population stemming from the Arab Muslim communities in Columbia, Kansas City, and St. Louis, Missouri. Binary logistic regression and Chi-square tests were used to analyze this quantitative data through SPSS while thematic analysis was used to analyze the qualitative data. The resulting analysis showed that first-generation immigrants tended to be more collectivistic, have a higher level of religiosity, and utilize a wider variety of conflict management styles including obliging, compromising, integrating, and avoiding. In addition, gender had a significant relationship only with the avoiding conflict management style, while level of religiosity had a significant relationship with the obliging, compromising, integrating, and dominating conflict management styles. Finally, culture had a significant predictive relationship with integrating and avoiding conflict management styles.
\end{abstract}

Keywords: conflict management styles, Arab, immigrants, Muslim, culture, religiosity, gender

\section{Introduction}

\subsection{Background Information}

The immigrant population in the United States has grown considerably over the last 50 years, more than doubling since the 1960s. In 1990, the immigrant population was 19.8 million, which increased to 31.4 million in 2000, and reached a record of 40.4 million by 2011 (U.S. Census Bureau, 2011). The Arab immigrant population in the United States has also increased, accounting for about 2.5 percent of the total immigrant population in 2009. According to the United States Census Bureau, the Arab immigrant population was slightly over one million, which more than tripled to 3.5 million in 2010, indicating a greater rate of increase than that of the overall immigrant population (U.S. Census Bureau, 2011).

As members of the United States workforce, Arab Muslim immigrants make important contributions in their fields. The American workforce includes governmental and non-governmental workers and has become increasingly heterogeneous. The Arab Muslim immigrant newcomers leave their mother culture and move to the United States, which starts the acculturation process. In some cases, acculturation can lead to some obstacles, especially in the work environment. Cultural differences between workers and the organizations they work for can lead to misunderstandings and ultimately conflicts in the workplace (Elsayed-Ekhouly, 1996). In fact, cultural differences can exist between workers from different cities within the same nation (Fitzsimmons, 2013).

The ultimate goal of any organization is to bring together individuals such that they unite to perform a designated mission in order to achieve specific goals (Bernard, Goldstein, \& Hazy, 2006). As organizations aim to increase the diversity of their workers, conflict becomes inevitable, necessitating members within the organization to decide their approach to conflict based upon their culture (LeBaron \& Zumeta, 2003). Conflict is, 
therefore, a consequence of organizational (and workplace) communication within organizations (Cetin \& Hacifazlioglu, 2004). Figure 1 illustrates the 5 main conflict management styles.

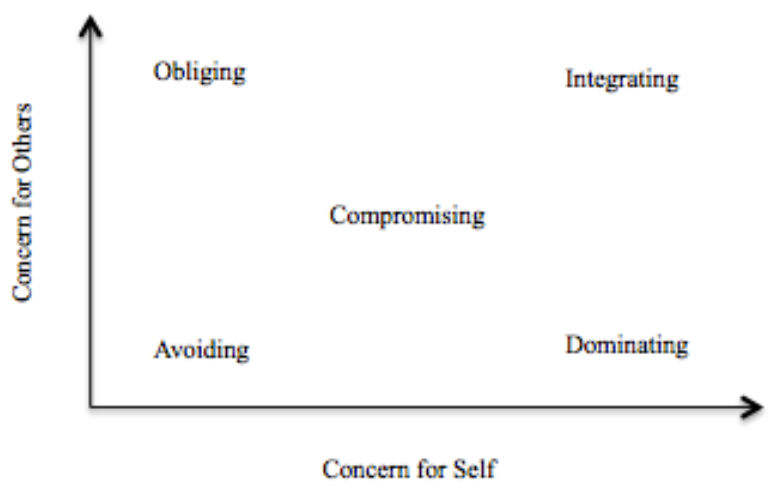

Figure 1. Conflict management styles

Multiple studies have shown that cultural differences have been identified as a source of project failure within organizations (Dinsmoer, 1984; Jaeger \& Kanungo, 1990; Muriithi \& Crawford, 2003). There is a clear gap in the literature, however, when it comes to examining workplace conflict for Arab Muslim immigrants in the United States.

The role of gender in determining an individual's choice of conflict management style has also been researched extensively in the literature (Heim \& Murphy, 2001; Jordan, 2001; Nelson \& Lubin, 1991; Rojahn \& Willemsen, 1994; Rowley, 2010; Shockley-Zalabak, 1981). The literature on gender's role in conflict management has fluctuated and remains inconsistent. Some researchers argue that gender plays a significant role in conflict management styles (Nelson \& Lubin, 1991) while other scholars argue that gender provides no significant role in choice of conflict management style (Kim et al., 2007).

The role of religion has also been investigated in the literature when it comes to determining conflict management styles. Alison (1975) and Geertz (1973) argue that religion, for most people, is the main cultural pillar through which they identify themselves. Randeree (2008) argued that the majority of Muslims utilize Islamic values to resolve their conflicts. Interestingly, Abdalla (2001) expands on this concept by arguing that Muslims also sometimes manage interpersonal conflict via Western techniques so long as these techniques don't conflict with Islamic teachings.

\subsection{Research Questions and Hypotheses}

This study explores how culture, gender, and level of religiosity of first generation Arab Muslim immigrants in the United States impact their choice of conflict management styles to resolve interpersonal conflicts in the workplace. Because Arab Muslim immigrants come to the United States with differing cultures, their norms differ from those of United States culture. In the workplace, differences in expectations regarding workplace nature, norms, and interpersonal relations with co-workers, gender roles, and religious values can create conflicts. Because Arab Muslim immigrants come from a different cultural background, they will likely utilize different conflict management styles. The question becomes can culture, gender, and level of religiosity predict conflict management styles utilized in the workplace by first generation Arab Muslim immigrants in the United States? Below are the overall research questions, sub-questions, and appropriate hypotheses for this research study.

RQ1: What are the overall trends in conflict management style preferences in the workplace for the first generation Arab Muslim immigrants in the United States?

-H1a: First generation Arab Muslim immigrants will have significantly higher scores on avoiding, obliging, compromising, and integrating in managing their interpersonal conflict.

RQ2. Is there a predictive relationship between culture (Individualism vs. Collectivism), gender, and level of religiosity and using obliging to manage interpersonal conflict in the workplace for first generation Arab Muslim immigrants in the United States? 
-Ho2: There will be no predictive relationship between culture (Individualism vs. Collectivism), gender, and level of religiosity and using obliging to manage interpersonal conflict in the workplace for the first generation of Arab Muslim immigrants.

-Ha2: There will be a predictive relationship between culture (Individualism vs. Collectivism), gender, and level of religiosity and using obliging to manage interpersonal conflict in the workplace for the first generation of Arab Muslim immigrants.

RQ3. Is there a predictive relationship between culture (Individualism vs. Collectivism), gender, and level of religiosity and using compromising to manage interpersonal conflict in the workplace for first generation Arab Muslim immigrants in the United States?

-Ho3: There will be no predictive relationship between culture (Individualism vs. Collectivism), gender, and level of religiosity and using compromising to manage interpersonal conflict in the workplace for the first generation of Arab Muslim immigrants.

-Ha3: There will be a predictive relationship between culture (Individualism vs. Collectivism), gender, and level of religiosity and using compromising to manage interpersonal conflict in the workplace for the first generation of Arab Muslim immigrants.

RQ4. Is there a predictive relationship between culture (Individualism vs. Collectivism), gender, and level of religiosity and using integrating to manage interpersonal conflict in the workplace for the first Arab Muslim immigrants in the United States?

-Ho4: There will be no predictive relationship between culture (Individualism vs. Collectivism), gender, and level of religiosity and using integrating to manage interpersonal conflict in the workplace for the first generation Arab Muslim immigrants.

-Ha4: There will be a predictive relationship between culture (Individualism vs. Collectivism), gender, and level of religiosity and using integrating to manage interpersonal conflict in the workplace for the first generation Arab Muslim immigrants.

RQ5. Is there a predictive relationship between culture (Individualism vs. Collectivism), gender, and level of religiosity and using avoiding to manage interpersonal conflict in the workplace for the first generation Arab Muslim immigrants in the United States?

-Ho5: There will be no predictive relationship between culture (Individualism vs. Collectivism), gender, and level of religiosity and using avoiding to manage interpersonal conflict in the workplace for the first generation Arab Muslim immigrants.

-Ha5: There will be a predictive relationship between culture (Individualism vs. Collectivism), gender, and level of religiosity and using avoiding to manage interpersonal conflict in the workplace for the first generation Arab Muslim immigrants.

RQ6. Is there a predictive relationship between culture (Individualism vs. Collectivism), gender, and level of religiosity and using dominating to manage interpersonal conflict in the workplace for the first generation Arab Muslim immigrants in the United States?

-Ho6: There will be no predictive relationship between culture (Individualism vs. Collectivism), gender, and level of religiosity and using dominating to manage interpersonal conflict in the workplace for the first generation Arab Muslim immigrants.

-Ha6: There will be a predictive relationship between culture (Individualism vs. Collectivism), gender, and level of religiosity and using dominating to manage interpersonal conflict in the workplace for the first generation Arab Muslim immigrants.

\section{Literature Review}

Certainly, culture plays a major role in an individuals' perception of conflict (Hofstede, 1980) and their chosen conflict management style (Davidhizar, 2004; Tjosvold \& Wong, 2004). In order to better understand how culture influences workplace conflict and the way that conflict is ultimately resolved, a full literature review of peer-reviewed literature is included

\subsection{Organizational Conflict}

Conflict is a widely defined topic within the literature. It occurs when an individual perceives differences with others about interests, beliefs, or values that are important (Starks, 2006) or perceives interference with the accomplishment of goals (Greenberg et al., 2003). Rahim (2002) expanded on this definition, specifying that 
conflict is "an interactive process manifested in an incompatibility, disagreement, or dissonance within or between social entities" (p. 207).

Workplace conflict wastes the time of managers, impacting the bottom lines of organizations, and impacting the growth and development of the organizations (Alzawahreh \& Khasawneh, 2011). One study showed that managers spent up to 20 percent of their valuable time dealing with organizational conflict and that conflict management is an issue of increasing importance within the organization (Thomas \& Schmidt, 1976).

Given the diversity in the workplace, it is expected that conflict becomes a normal, natural result of interpersonal communication. This occurs with every relationship because it brings individuals from all cultures together, forcing them to acquire skills to manage conflict. The ways in which culture impacts the conflict management styles of individuals has a broad influence due to its impact on the economic and social levels of the organizations. Therefore, identifying potential differences in conflict management styles between Arab Muslim immigrants and their co-workers could potentially lead to earlier solutions to problems in the workplace, limiting the costs associated with prolonged conflict in the workplace.

Many studies have shown that cultures differ in their preferred forms of handling conflict (Chua \& Gudykunst, 1987; Elsayed-Ekhouly \& Buda, 1996; Leung, 1987; Morris et al., 1998; Ting-Toomey et al., 2000; Trubisky, Ting-Toomey, \& Lin, 1991; He, Zhu, \& Peng, 2002). Elsayed-Ekhouly and Buda (1996) examined the impact of culture on styles of handling interpersonal conflicts and found that Arab executives use more of an integrating and avoiding style in handling interpersonal conflicts at work while their American counterparts use more of an obliging, dominating, and compromising style. Rahim (2001) suggested that people from individualistic cultures utilize a dominating or obliging style to resolve their conflicts. This is supported by a study conducted by Trubisky and Ting-Toomey (2000) found that Taiwanese students used obliging and avoiding styles more than United States students when faced with conflicts.

\subsection{Individualism versus Collectivism}

Hofstede (1980) defined culture as "the collective programming of the mind which distinguishes one group or category from another" (p. 89). He also categorized cultural differences based on four dimensions: power distance, uncertainty avoidance, individualism versus collectivism, and masculinity versus femininity (Hofstede, 1993). Power distance refers to the degree of accepted inequality that exists among people with and without power. The individualism score refers to the strength of ties that people have to the community, with a high score indicating a loose connection and a low score indicating a more collectivistic society (Hofstede, 1980).

Hofstede (2010) expanded on these dimensions by adding "long-term versus short-term orientation," which was rooted in Michael Harries Bond's "Confucian work dynamism). Also, adding the sixth dimension, "indulgence versus restraint", was developed by Minkov, a Bulgarian scholar, who was invited by Hofstede and his son to co-author their third edition of the Cultures and Organizations: Software of the Mind

Studies have shown that one's cultural background, whether based on individualism or collectivism, has a significant impact on the individual's choice of conflict management styles (Rahim \& Blum, 1994).

The division between individualistic cultures and collectivistic cultures has been widely used in cross-cultural research (Hofstede, 1980; Ting-Toomey, 1988; Hofstede, 2001; Gudykunst et al., 1996; Kozan, 1989). Those from individualistic cultures value their own personal goals over those of the group. Their counterparts from collectivistic cultures, on the other hand, value the groups' needs and values over those of the individual (Markus \& Kitayama, 1991).

While the individualist's focus on the goals and concerns of the self, the collectivist focus was on relationship (Triandis, 2006) and the concerns and goals of the group (Cai \& Fink, 2002). Conflicts arise when individuals abide by individualistic norms in a collectivist society. Similarly, conflicts also arise when individuals adhere to collectivist norms in an individualistic society (Kozan, 2002). Furthermore, researchers have labeled societies such as African, Arab, Asian, Eastern European, and those with Latin roots as collectivist-oriented and those with American, Canadian, Australian, and Western European countries as individualistic (Cai \& Fink, 2002; Chiu, Wong, \& Kosinski, 1998; Hofstede, 2001).

Many scholars have examined the differences in individualistic and collectivistic cultural logics and scripts and how they result in differing notions of what constitutes proper treatment by others (Hofstede, 2012; Leung \& Cohen, 2011; Oetzel et al., 2001). In individualistic cultures, people are expected to look after themselves and their closest kin. On the other hand, individuals from collectivistic cultures are expected to show unconditional loyalty and support not only for their extended families, but also for members of particular in-groups (Hofstede, 2012). 
There are many reasons for conflict among individuals with different cultural background in the workplace. Leung and Cohen (2011) suggested that cultural logics and behaviors lead to "a certain logical consistency and coherence for the people of a culture" (p. 508). These logics and scripts are often invisible to outsiders, which make them easily violated by those from a different culture. This in turn leads to conflict. Wagner (1995) suggested that when personal and group interests reach a conflict, individualists tend to give less of a concern to the group's interests. Collectivists give greater concern to the overall group's needs and interests. When those from individualistic and collectivistic cultures constitute the group, then it is easy to recognize how conflicts can arise. Given the differing cultural backgrounds of Arab Muslim immigrants compared to their American counterparts, it is also essential to investigate the differences in conflict management styles utilized by each group.

\subsection{The Role of Gender}

As previously discussed, multiple studies have investigated the role of gender in determining conflict management styles utilized by individuals. Mills and Chusmi (1988) investigated managers in the United States and found that males tended to use the forcing, competing, and problem solving conflict management styles compared with their female counterparts.

Other studies found similar results in their investigations of the role of gender in predicting conflict management styles (Lindeman et al., 1997; Polkinghorn \& Byme, 2001; French et al., 2005; Osisioma, 2009). It should be noted, however, that some investigations by scholars showed that gender does not seem to influence people's conflict management styles. Haare and Krahe (1999) investigated Indonesian and German children and tried to determine whether gender and culture influenced their conflict management style. They concluded that while culture did have an influence on interpersonal conflict management styles, gender did not have any significant role in the matter. This inconsistency in the literature indicates the need for more larger scale studies on the role of gender in predicting conflict management styles.

\subsection{The Role of Religiosity}

As discussed in the introduction, there are many studies that have investigated the role of religion as a predictor for the conflict management styles utilized by individuals. Polkinghorn and Byrne (2001) found that participants from different religious backgrounds used different conflict management styles to address their conflicts. Croucher (2011) investigated how religion, specifically Islam and Christianity in Western Europe, influenced the way participants managed their interpersonal conflicts. Croucher found that religion did have a significant impact on participants' preference of conflict management styles. Specifically, Muslims preferred more compromising and obliging conflict management styles while Christians preferred the dominating styles overall. In addition to the multiple studies investigating the role of religion in predicting conflict management styles (Alison, 1975; Geertz, 1973; Randeree, 2008; Abdalla, 2001). Wilson and Power (2004) investigated the role of religiosity in impacting conflict management styles. This study was unique in that it assessed the extent to which individuals practiced their major religious requirements, and whether this predicted their choice of conflict management styles. The study found that Christians (practicing and non-practicing) and non-practicing Muslims tended to collaborate when dealing with conflicts, while practicing Muslims who correlated themselves with a higher level of religiosity preferred utilizing the compromising style for managing their conflicts (Wilson \& Power, 2004). The authors hypothesized that "this difference in Australian practicing Muslims could be a reflection of their minority status in that less dominant groups have to 'fit in' more with the dominant culture and thus become practiced at compromising" (p. 80), an argument which goes back to the acculturation process of immigrants that will be addressed in my research study.

\subsection{Conflict Management Styles}

As highlighted in the introduction, different conflict management styles are defined based on general and consistent orientation toward the opposing/conflicting party and the conflict. They manifest in observable behaviors that form a pattern and share common characteristics over time (Ruble \& Thomas, 1976; Thomas, 1976; Thomas \& Kilmann, 1978). While the goal of most conflicting parties is to handle the conflict, researchers have found that individuals vary in their ways of approaching their interpersonal conflict (Lulofs \& Cahn, 2000).

Researchers have identified conflict management based on concern for self and for others, classifying the concerns based on high or low concern. This is attributed to the dual concern theory, which proposed five styles for handling conflict (Blake \& Mouton, 1964; Rahim, 1983; Thomas, 1976). The dual concern model is rooted in Blake and Mouton's (1964) theory that conflict is managed in different ways based on whether a manager has a high or low concern for production and high or low concern for people. These two dimensions led to the five ways of handling conflict. 
The majority of scholars have agreed upon the five patterns of conflict management styles introduced by Black and Mouton in 1964 and expanded by Thomas and Killman (1975) as well as Rahim (1983). Rahim categorized the five patterns approach as follows: avoiding, obliging, dominating, integrating, and compromising. Avoiding is associated with intentionally withdrawing from the conflict situation, with a low concern for others as well as a low concern for self. The obliging style focuses on areas of agreement and sets aside differences. This style tends to reflect the individuals' concern with others' needs over personal needs and views. Dominating reflects low concern for others and a high concern for self and is described as forcing one's own views on others. The integrating style reflects high concern for others and high concern for self, an approach that strives to integrate the views of all those involved. The final conflict management style, of compromising, reflects moderate concern for all and is associated with finding a middle ground based on a common solution that addresses everyone's interest.

In a study investigating the conflict management styles of managers from collectivistic (Japan, China, Korea, Taiwan, and the Middle East) and individualistic societies (the United States), the authors found that the managers from collectivistic societies were less confrontational, and more likely to use a group interaction to overcome conflict compared to their individualistic manager counterparts (Ting-Toomey \& Oetzel, 2001). Rahim (2001) found that individualists tend to use dominating or obliging approaches in solving their interpersonal conflicts, while their collectivist counterparts use integrative (such as collaborative or accommodation) approaches

Kozan (1989) conducted a study comparing Arab Muslim managers in Jordan and Turkey with American managers. He found that Jordanian and Turkish managers shared similar conflict management styles, clearly preferring the collaborative style in handling their conflicts. On the other hand, the American managers preferred force and accommodation. This is yet another example of how individuals from more collectivistic societies resolve conflict in a different manner compared to their peers from individualistic societies. Similar findings were found in other studies comparing individuals from collectivistic and individualistic cultures (Trubisky et al., 1991; Fletcher et al., 1998; Elsayed-Akhouly \& Budy, 1996).

\section{Methodology}

\subsection{Research Design}

A two-phase methodology, sequential explanatory (Creswell, 2013) mixed-method study was used to explore whether gender, religiosity, and cultural variations impact conflict management styles utilized by Arab Muslim immigrants in the workplace. Phase one was a quantitative study that looked at the statistical relationships between gender, religiosity, and cultural variation and conflict management styles utilized by 145 participants. Following this macro analysis, phase two utilized a qualitative study approach in order to better understand the dynamics of certain conflict management styles by conducting semi-structured face-to-face interviews with 12 participants.

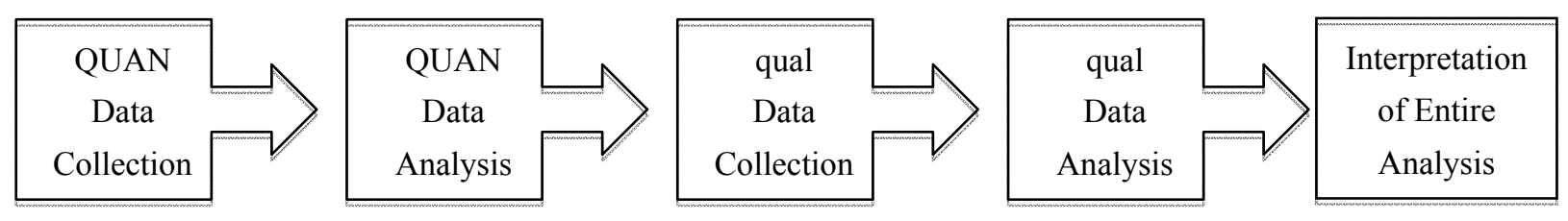

Figure 2. Sequential explanatory mixed method approach

In this study, phase one includes surveys, which were sent to three major Muslim communities in Missouri, specifically, in Columbia, Kansas City, and St. Louis. After data analysis was completed for the surveys, phase two followed with 12 semi-structured face-to-face interviews.

\subsection{Operationalization}

For the purposes of this study, a first generation participant is defined as an individual who immigrated to the United States from an Arab country (Britto \& Amer, 2007). Please refer to Table 1 for definitions of each of the different conflict management styles, which make up the dependent variables for this study. 
Table 1. Conflict management styles

\begin{tabular}{ll}
$\begin{array}{l}\text { Conflict management } \\
\text { style }\end{array}$ & Definition \\
\hline Dominating & $\begin{array}{l}\text { Individuals seek to satisfy their own interests regardless of the impact on other parties in the conflict (Robbins et } \\
\text { al., 2008). } \\
\text { Win-win resolution where it is assumed that the solution to the conflict can leave both parties in a better condition } \\
\text { (Johnson \& Johnson, 1994). }\end{array}$ \\
Antegrating & $\begin{array}{l}\text { Ignoring or suppressing a conflict in the hope that it will go away or won't become too destructive (Johns, 1994). } \\
\text { When one party in the conflict is willing to place the opponent's interest above his or her own (Johnson \& } \\
\text { Obliging }\end{array}$ \\
Johnson, 1994). \\
No clear winner or loser; each party to the conflict is willing to give up something to come to a resolution \\
(Johnson \& Johnson, 1994).
\end{tabular}

\subsection{Validity}

This research design triangulated between different sources and sampling methods. Investigating Arab Muslim American from three different communities also increased the validity of the results (Bailey, White, \& Pain, 1999). Triangulation was employed through multiple sources: families from three different Arab Muslim American communities, each community providing a different perspective on the behavior of handling their conflict (Konecki, 2008). I also triangulated by including a mixed-method approach (quantitative and qualitative) by using the interviews to investigate and help understand findings from the quantitative component, thus effectively increasing the study's internal validity. With a triangulation approach including surveys and face-to-face interviews, each method provides benefits that overlap with the weaknesses of other methods utilized in this study.

\subsection{Sampling}

For phase I of the study, a probability random sampling technique was utilized to select units from this study's population to participate in the survey.

A total of 225 surveys, 75 for each city, were sent out, however, only 145 surveys were completed and returned. The leaders of each of the three Muslim communities were contacted, and an invitation email to participate in the surveys was sent out to the first 75 emails from each of the three Muslim communities.

For phase II of the study, a snowball approach was utilized to select potential participants for interview. After identifying some individuals for preliminary interviews, I consulted with these participants for their recommendations for other individuals to interview. A total of 12 participants were interviewed, including two males and two females from each of the Muslim communities.

\subsection{Phase I: Quantitative Study}

\subsubsection{Data Collection Method}

An anonymous online surveys were used in phase one of the study. The survey process extended over the course of three months. Three different scales were used in this survey: religiosity scale, culture, individualism vs. collectivism scale, and conflict management style scale.

\subsubsection{Instruments}

\subsubsection{Individualism-Collectivism Scale and Its Reliability (INDCOL)}

This scale was derived from the original (INDCOL), which was designed by Hui and Triandas (1986). The original scale was a 66-item Likert scale, however, Cai and Fink (2002), adjusted this scale into one consisting of 11 items. This 11 -item scale scored on reliability Cronbach's $\alpha=.76$. Participants were asked to respond to the 11-item questionnaire on a 5-point Likert scale.

\subsubsection{Conflict Management Styles Scale and Its Reliability (ROCI-II)}

The 28-item Rahim Organizational Conflict Inventory-II (ROCI-II) was used to assess conflict management styles (Rahim, 2001). This scale measures the five conflict management styles: avoiding Cronbach's $\alpha=.84$; compromising Cronbach's $\alpha=.75$; dominating Cronbach's $\alpha=.84$; integrating Cronbach's $\alpha=.81$; and obliging Cronbach's $\alpha=.83$. 


\subsubsection{The Centrality of Religiosity Scale Reliability (CRS)}

This scale was used to investigate the religiosity of each of the study participants. This scale is designed to measure five sides of religiosity. These dimensions are: public practice, religious experience, ideology, private practice, and the intellectual practice (Huber, 2012). Reliabilities of the individual dimensions ranged from 0.80 to 0.93 , and from 0.92 to 0.96 for the whole CRS- 15 .

\subsubsection{Participants}

All 145 subjects in this study participated on a voluntarily basis. First generation respondents, 86 were male respondents (59.3\% of total respondents) and 59 were female respondents (40.7\% of total respondents). Participants came from 16 countries, including Palestine $(n=36)$, Jordan $(n=27)$, Yemen $(n=9)$, Lebanon $(n=$ 7), Syria $(n=10)$, Sudan $(n=3)$, Tunisia $(n=5)$, Oman $(n=1)$, Morocco $(n=5)$, Bahrain $(n=1)$, Iraq $(n=29)$, Somalia $(\mathrm{n}=3)$, Qatar $(\mathrm{n}=2)$, Libya $(\mathrm{n}=5)$, Kuwait $(\mathrm{n}=1)$, and Djibouti $(\mathrm{n}=1)$.

\subsection{Phase II: Qualitative Study}

\subsubsection{Data Collection Method}

The quantitative study was followed by 12 face-to-face semi-structured interviews, which provided a more in-depth knowledge about why each generation used a certain conflict management style to handle their interpersonal conflict in the workplace. Specifically, what made some individuals choose one conflict management style over the other?

\subsubsection{Participants}

A total of 12 interviews were conducted and included participants from six different countries including Jordan, Libya, Tunisia, Palestine, Egypt, and Iraq. They included male and female participants who were first generation immigrants. Please refer to Table 6.2 for full demographic information for each of the interviewees.

Table 2. Phase II interview participants

\begin{tabular}{lll}
\hline Interviewee & Gender & Country of origin \\
\hline FGF6 & Female & Jordan \\
FGM7 & Male & Jordan \\
FGF8 & Female & Libya \\
FGF9 & Female & Palestine \\
FGM11 & Male & Libya \\
FGF15 & Female & Tunisia \\
FGF17 & Female & Egypt \\
FGM19 & Male & Tunisia \\
FGF20 & Female & Iraq \\
FGM21 & Male & Palestine \\
FGM23 & Male & Egypt \\
FGM24 & Male & Iraq \\
\hline
\end{tabular}

\section{Results}

\subsection{Phase I: Quantitative Data Analysis}

The independent variables (IDVs) were operationalized as following: Gender was operationalized as a dichotomous variable $(1=$ Male; $2=$ Female $)$, Culture was operationalized as a dichotomous variable $(1=$ Collectivism; 2 = Individualism), and level of religiosity was operationalized as a dichotomous variable $(1=$ High religiosity; 2 = low religiosity). The dependent variable (DV) as a categorical variable takes five conflict management styles. Therefore, the five categories of conflict management styles include: Obliging $(0=$ no obliging; $1=$ yes obliging $)$, Compromising $(0=$ no compromising; $1=$ yes compromising $)$, Integrating $(0=$ no integrating; $1=$ yes integrating), Avoiding $(0=$ no avoiding; $1=$ yes avoiding $)$, and Dominating $(0=$ no dominating; 1 = yes dominating).

Question 1. The first research question's results were analyzed using the chi-square test. The first research question in this study was, what is the overall trend in conflict management style preferences for the first generations in the workplace of Arab Muslim immigrants in the United States?

The first analysis explores whether there is a significant association between culture (individualistic or 
collectivistic) and first generation immigrant. The cross tabulation statistics suggest that there was a significant association. In fact, the first generation immigrant tends to be more collectivists (95.9 percent). When assessing for a potential significant association between religiosity and being a first generation immigrant, the research showed that 74.5 percent of first generation Arab Muslim immigrants in this study identified themselves as having a high level of religiosity.

In conducting the chi-square analysis for each of the conflict management styles, certain trends are identified (refer to Table 3). First, a chi-square analysis was done to explore whether there was an association between the obliging as a conflict management style and being a first generation Arab Muslim immigrant. Based on the results it appears that the first-generation immigrants were more likely to utilize obliging conflict management styles (80.0 percent of first-generation immigrants). The association between obliging as a conflict management style and the first generation status of the participant was statistically significant with a $p$ value of 0.014 .

Table 3. Chi-Square analysis question 1

\begin{tabular}{llll}
\hline & Value & df & Asymp. Sig. (2-sided) \\
\hline Culture Pearson Chi-Square & $172.442^{\mathrm{a}}$ & 1 & .000 \\
Religion Pearson Chi-Square & $62.102^{\mathrm{b}}$ & 1 & .000 \\
Obliging Pearson Chi-Square & $4.931^{\mathrm{c}}$ & 1 & .014 \\
Compromising Pearson Chi-Square & $6.361^{\mathrm{d}}$ & 1 & .001 \\
Integrating Pearson Chi-Square & $10.600^{\mathrm{e}}$ & 1 & .001 \\
Avoiding Pearson Chi-Square & $8.415^{\mathrm{f}}$ & 1 & .002 \\
Dominating Pearson Chi-Square & $51.937^{\mathrm{g}}$ & 1 & .000 \\
\hline
\end{tabular}

a. $\quad 0$ cells have expected count less than 5 . The minimum expected count is 44.02 .

b. $\quad 0$ cells have expected count less than 5 . The minimum expected count is 52.73 .

c. $\quad 0$ cells have expected count less than 5 . The minimum expected count is 28.33 .

d. 0 cells have expected count less than 5 . The minimum expected count is 29.20 .

e. $\quad 0$ cells have expected count less than 5 . The minimum expected count is 31.38 .

f. $\quad 0$ cells have expected count less than 5 . The minimum expected count is 54.47.

g. 0 cells have expected count less than 5 . The minimum expected count is 40.53 .

An association was also identified between the compromising as a conflict management style and being a first generation immigrant. In fact, first-generation immigrants were more likely to use compromising ( 80.0 percent) strategies. This result was also statistically significant, with a $p$ value of 0.001 . An association was also identified between first generation immigrants status and utilizing the integrating as a conflict management style. Again in this case, the first-generation immigrants were more likely to utilize integrating strategies $(80.0$ percent of the time). This also was statistically significant, with a p-value of 0.001 .

First-generation immigrants were also more likely to utilize avoiding as a conflict management styles. In fact, first-generation immigrants utilized avoiding methods to address their interpersonal conflict up to 59.3 percent of the time. This difference in the extent of utilizing avoiding strategies for their interpersonal conflicts was statistically significant with a $\mathrm{p}$ value of 0.002 .

The dominating conflict management style was the only form that was less likely to be utilized by first generation immigrants. First generation immigrants only reported utilizing dominating conflict management styles up to 44.8 percent of the time. Based on the chi-square analysis, this association was also statistically significant with a $\mathrm{p}$ value of $<0.001$. In summary, first-generation immigrants were more likely to identify with a collectivistic culture, have a higher level of religiosity, and utilize obliging, compromising, integrating, and avoiding conflict management styles.

Question 2. As was discussed in the introduction, question 2 investigates whether there is a predictive relationship between culture (individualism vs. collectivism), gender, and level of religiosity and using obliging to manage interpersonal conflict in the workplace for the first generation Arab Muslim immigrants in the United States. Based on the results, religiosity $(p=0.001)$ and culture $(p=0.02)$ had a significant relationship with utilizing obliging to manage interpersonal conflicts in the workplace. Gender $(p=0.291)$ did not have a significant predictive relationship with utilizing obliging as a conflict management style. 
Table 4. Binary logistic regression for obliging conflict management style

\begin{tabular}{|c|c|c|c|c|c|c|c|}
\hline Step 1a & & $\mathrm{B}$ & S.E. & Wald & $\mathrm{df}$ & Sig. & $\operatorname{Exp}(B)$ \\
\hline Gender (1) & & -.232 & .299 & .758 & 1 & .291 & .838 \\
\hline \multirow[t]{3}{*}{ Culture (1) } & Religion (1) Constant & -.524 & .263 & 2.998 & 1 & .02 & .310 \\
\hline & & -.783 & .199 & 3.435 & 1 & .001 & 3.19 \\
\hline & & 4.365 & .714 & 25.557 & 1 & .000 & 46.647 \\
\hline
\end{tabular}

a Variable(s) entered on step 1: Gender, Culture, Religion.

Question 3. Question 3 investigates whether there is a predictive relationship between culture (individualism vs. collectivism), gender, and level of religiosity and using compromising to manage interpersonal conflict in the workplace for the first generation Arab Muslim immigrants in the United States. All three variables, level of religiosity $(p=0.003)$, Gender $(p=0.000)$, and culture $(p=0.001)$, had a significant predictive relationship with the compromising conflict management style.

Table 5. Binary logistic regression for compromising conflict management style

\begin{tabular}{|c|c|c|c|c|c|c|c|c|}
\hline Step 1a & & & B & S.E. & Wald & $\mathrm{df}$ & Sig. & $\operatorname{Exp}(B)$ \\
\hline Gender (1) & & & -.235 & .217 & 2.201 & 1 & .000 & .265 \\
\hline \multirow[t]{3}{*}{ Culture (1) } & Religion (1) & Constant & -.384 & .264 & 2.354 & 1 & .001 & .313 \\
\hline & & & -.624 & .301 & 6.243 & 1 & .003 & 3.98 \\
\hline & & & -.3 .587 & .708 & 25.677 & 1 & .000 & 36.125 \\
\hline
\end{tabular}

a Variable(s) entered on step 1: Gender, Culture, Religion.

Question 4. Question 4 investigates whether there is a predictive relationship between culture (individualism vs. collectivism), gender, and level of religiosity and using integrating to manage interpersonal conflict in the workplace for the first generation Arab Muslim immigrants in the United States. We found that culture ( $p=$ $0.005)$ and level of religiosity $(\mathrm{p}=0.03)$ had predictive relationships with utilizing integrating as a conflict management style to manage their interpersonal conflicts in the workplace. However, gender $(p=0.52)$ had no predictive relationship with integrating.

Table 6. Binary logistic regression for integrating conflict management style

\begin{tabular}{|c|c|c|c|c|c|c|c|}
\hline Step 1a & & B & S.E. & Wald & $\mathrm{df}$ & Sig. & $\operatorname{Exp}(B)$ \\
\hline Gender (1) & & -.524 & .198 & 3.110 & 1 & .52 & .534 \\
\hline Culture (1) & & -.524 & .173 & 5.653 & 1 & .005 & 6.534 \\
\hline Religion & (1) & -.672 & .199 & 4.763 & 1 & .03 & 3.713 \\
\hline Constant & & 3.784 & .714 & 21.342 & 1 & .000 & 64.569 \\
\hline
\end{tabular}

a Variable(s) entered on step 1: Gender, Culture, Religion.

Question 5. Question 5 investigates whether there is a predictive relationship between culture (individualism vs. collectivism), gender, and level of religiosity and using avoiding to manage interpersonal conflict in the workplace for the first generation Arab Muslim immigrants in the United States. Utilizing binary logistic regression, gender $(\mathrm{p}=0.02)$ and culture $(\mathrm{p}=0.002)$ had significant predictive relationship with utilizing the avoiding conflict management style to manage their interpersonal conflicts in the workplace. Religiosity $(\mathrm{p}=$ 0.077), on the other hand, had no significant predictive relationship with utilizing the avoiding conflict management style. 
Table 7. Binary logistic regression for avoiding conflict management style

\begin{tabular}{|c|c|c|c|c|c|c|c|}
\hline Step 1a & & $\mathrm{B}$ & S.E. & Wald & $\mathrm{df}$ & Sig. & $\operatorname{Exp}(B)$ \\
\hline Gender (1) & & -.253 & .152 & 5.243 & 1 & .02 & 3.63 \\
\hline Culture & (1) & -.534 & .253 & 3.234 & 1 & .002 & 3.98 \\
\hline Religion & (1) & -.243 & .209 & 2.253 & 1 & .077 & .872 \\
\hline Constant & & 4.245 & .534 & 32.534 & 1 & .000 & 22.722 \\
\hline
\end{tabular}

a Variable(s) entered on step 1: Gender, Culture, Religion.

Question 6. Question 5 investigates whether there is a predictive relationship between culture (individualism vs. collectivism), gender, and level of religiosity and using dominating to manage interpersonal conflict in the workplace for the first generation Arab Muslim immigrants in the United States. Gender $(p=0.000)$, culture $(p=$ $0.04)$, and level of religiosity $(\mathrm{p}=0.000)$ had a significant predictive relationship with utilizing the dominating conflict management style for managing their interpersonal conflict in the workplace.

Table 8. Binary logistic regression for dominating conflict management style

\begin{tabular}{|c|c|c|c|c|c|c|}
\hline Step 1a & $\mathrm{B}$ & S.E. & Wald & df & Sig. & $\operatorname{Exp}(B)$ \\
\hline Gender (1) Culture & -.735 & .142 & 5.534 & 1 & .000 & 3.34 \\
\hline (1) & -.534 & .243 & .235 & 1 & .04 & 3.354 \\
\hline Religion & -1.354 & .654 & 7.153 & 1 & .000 & 3.34 \\
\hline Constant & 4.546 & .654 & 19.439 & 1 & .000 & 23.869 \\
\hline
\end{tabular}

a Variable(s) entered on step 1: Gender, Culture, Religion.

\subsection{Phase II: Qualitative Data Analysis}

The results of the quantitative portion of the study are used to guide the qualitative phase. In this study, I focused on the results of research question 1 specifically to guide the qualitative component of the study. The first research question in this study was, what is the overall trend in conflict management style preferences among the first generations in the workplace of Arab Muslim immigrants in the United States. Based on the quantitative results, the interview guide for the qualitative component of the study was modeled to explore why first generation immigrants were more likely to identify with a collectivistic culture, have a higher level of religiosity, and utilize obliging, compromising, integrating, and avoiding conflict management styles.

To organize each of the transcribed interviews, a simple coding system for each interview was utilized. Specifically, FGM refers to a first generation male, and FGF refers to a first-generation female. In addition, a number following the code was utilized to identify the interview number.

\subsubsection{Culture}

In phase I of the study, first-generation immigrants were more likely to identify with a collectivistic culture. This trend was also identified in the interviews. Many interview participants relayed a sensation of being homesick, and specifically missing many components of their culture back home (FGM23; FGF15; FGF6; FGM7). Most of the interview participants in this study did not use the labels of compromising, avoiding, obliging, etc. Rather, they often described one of these conflict management styles in their interviews:

I am used to being surrounded by my family. Actually, I think this is one of the biggest things I miss back home. We used to all gather at the end of the day and talk about our work, our fun, everything. I still have some homesick inside of me and this causes me so much stress. I overcome it, but it's not that easy. I don't want to stress at work, I feel that I have to work that much harder than all of my colleagues to be recognized. When I am at work, I just don't want to be known for being a troublemaker, so a lot of times if there is a conflict I will let things go, usually for the favor of my colleague. This satisfies my colleagues and just reduces my own stress, and I'm not identified as someone who causes trouble at work. Less trouble, less stress. (FGM21, personal communication, November 7, 2014).

In the case of this first-generation male immigrant, he seemed to have a level of stress getting used to being away from his family such that at work he settles for what appears to be an obliging conflict management style based on his description.

Struggling to work with some of their American counterparts due to differences in culture or conflict 
management styles was also emphasized in one of the interviews with first generation immigrants. He stated that interaction with Americans can be "badly disappointing at times," adding, "a win-win situation should be the ideal way to solve conflicts in the workplace, but I feel that American culture is all about every man for themselves. Why don't we work out our conflicts in a way that everyone is happy?" (FGM7, personal communication, September 21, 2014).

Actually, communication between first-generation immigrants and their American colleagues was noted to be a difficult source of conflict by other participants as well, and often, this was thought to be due to a lack of cultural sensitivity (FGM11, personal communication, October 2, 2014).

\subsubsection{Gender}

Unsurprisingly, phase II did provide valuable anecdotal data on the potential impact of gender on the conflict management styles utilized in the workplace both for first generation Arab Muslim immigrants in the United States.

However, when looking at first generation immigrants and their American counterparts, perhaps more disagreement occurs due to the wider gaps in cultural understanding based on different upbringings or differences in the country and culture they grew up in.

In one interview with a first-generation male immigrant, he relayed the differences in culture that he experienced when coming to the United States, and how this played a role in his choice of conflict management style utilized in the workplace:

Well, you know that we share the same masculine culture where maleness is one of the main pillars in societies. Not putting down female's roles. As you know, I don't need to explain to you how female are very respected there. Our roles in our societies built upon the idea that men can do everything and can do anything, however, when I started my job here, I noticed that it is slightly different. Your female colleague could confront you and argue strongly to an extent that would be considered unacceptable for females to back home. - (FGM11, personal communication, October 2, 2014)

This participant relayed that he came from a male-dominated culture, which turned into a surprise for him in the workplace, where a female colleague confronted him and argued about specific conflicts, something that could be considered unacceptable in his country of origin. He went on to state that this surprising experience in his workplace also helped him learn to work with his female colleagues in a more compromising way to solve their interpersonal conflicts in the workplace, something that he had to adapt to here in the United States.

\subsubsection{Level of Religiosity}

Many interview participants believed that religion played a significant role in their daily lives, and they identified themselves as having a high level of religiosity (FGF6, FGF8, FGF9, FGF17, FGM19, and FGM24). Some interview participants who identified with a high level of religiosity felt that their religiosity specifically played a role in how they handled interpersonal conflicts with their colleagues.

We are Muslims who see our religion as a life system that draws the borderlines of what we should do or what we should avoid. As a woman who grew up in the Middle East in a Muslim family, I have an expected set of rules on how women should deal with people from the same gender and the opposite gender. You know... I can't confront a male colleague and be so bold. I usually seek help from another female colleague on how to solve this problem or approach my boss, but if I know I could give to solve problem, I would do right away. - (FGF20, personal communication, November 7, 2014).

Interestingly, first generation female interviewee (FGF15, personal communication, October 12, 2014) who stated "religion is a big part of my everyday life, so it really impacts everything I do. Like when I have a conflict at work I don't just try to take advantage of my colleagues and dominate over them, I usually try to work with them to solve the problem, because for me my religion requires that."

In summary, many of the findings in the qualitative phase of the study reflected results that were found in the quantitative parts of the study, with a few exceptions and surprising results in some of the interviews

\section{Discussion}

The main goal of this study was to explore the extent to which the conflict management styles of first generation Arab Muslim immigrants in the United States are influenced by their culture, gender, and level of religiosity. The results of this study have provided an intriguing contribution to the cross-cultural research of conflict management and organizational conflict, specifically with a focus on Arab Muslim immigrants and their acculturation process in the United States. This following section discusses the overall findings in phase I and 
phase II of the study and the implications of the independent variables as predictors of utilization of each of the following conflict management styles: obliging, compromising, integrating, avoiding, and dominating.

\subsection{The Role of Culture}

It should be noted that this study focused on only one perspective of analyzing culture, specifically the comparison between individualism and collectivism. Culture is by definition complex, and there are many different ways to characterize culture. In my study, I chose to utilize individualistic vs. collectivistic culture. This is by no means a proxy for culture generally, but it does provide a perspective on culture.

Phase I of the study found that first-generation immigrants tended to be far more collectivistic $(95.9 \%)$ in their culture. Phase II similarly suggested that first generation immigrants were more likely to identify with a collectivistic culture (FGM23, FGF15, FGF6, FGM7). These findings could be attributed to a number of factors. Many first generation immigrants come to the United States with their own thoughts on their culture, and the intention to continue to maintain it (Chen \& Sheldon, 2012; Bisin \& Verdier, 2000). Oftentimes, first generation immigrants still find it difficult to assimilate or even integrate into the new culture, especially when they come in with the mentality that they want to maintain their own cultural norms.

I found that first generation Arab Muslim immigrants tended to utilize a variety of conflict management styles (more commonly obliging, compromising, integrating, and avoiding). Culture also had a predictive relationship with Arab Muslim immigrants utilizing the obliging $(p=0.02)$, compromising $(p=0.001)$, integrating $(p=$ $0.005)$, avoiding $(p=0.002)$, and dominating $(p=0.04)$ conflict management styles to help resolve their interpersonal conflicts in the workplace. These findings in part coincide with and yet also contradict the current literature. Rahim (2001) and Triandis (2006) found in their studies that there was a significant predictive relationship between culture and conflict management styles utilized. Rahim and Bonoma (1999) also suggested that culture could be a factor that influenced individuals to choose more than one conflict management style when faced with an interpersonal conflict.

This study's findings partially contradict findings by Lulofs and Cahn (2000) that managers from collectivistic cultures in the Middle East tended to dominate more than managers from individualistic cultures in the United States. My results do, however, support Ting-Toomey and Oetzel's (2001) study which instead found that individuals from collectivistic culture tended to utilize obliging and compromising conflict management styles compared to those from individualistic cultures. Chua and Gudykunst (1987) found that international students from collectivistic cultures utilize less dominating than students from more individualistic cultures. Kozan (1989) supported my findings that many Arab Muslim first generation immigrants utilize the integrating styles for solving their interpersonal conflicts.

My study found that first generation Arab Muslim immigrants were more likely to label their culture as collectivistic, and were more likely to utilize integrating, avoiding, compromising, and obliging conflict management styles. Interestingly, Rahim (2000) found that those from individualistic cultures were more likely to utilize dominating and obliging conflict management styles. Therefore, Rahim's findings partially coincide with my findings, in that those from individualist cultures were more likely to utilize dominating conflict management styles. On the other hand, Rahim also found that those from individualistic cultures were more likely to utilize obliging conflict management styles, which actually contradicts my findings that obliging was more likely to be utilized by first generation Arab Muslim and more collectivistic participants. Furthermore, Trubisky and Ting-Toomey (1991) found that collectivistic students preferred obliging and avoiding styles more than their individualistic counterparts, which also supports the findings in my study that first-generation immigrants (who tended to have a more collectivistic culture) were more likely to utilize obliging and avoiding styles. My study also found that these first-generation immigrants were more likely to adapt compromising and integrating conflict management styles.

Some plausible explanations for these findings could be based on the expectations of collectivistic cultures. First generation immigrants that were more likely to identify their culture as collectivistic valued the needs of the group and the success of the group over the needs and success of the individual. This may explain why the first generation immigrants were more likely to utilize a wider variety of conflict management styles and were less likely to utilize a dominating conflict management style. It is noteworthy that prioritizing the needs of the group is also an Islamic notion (Ali, 1992).

\subsection{The Role of Gender}

This study explores whether there is a predictive relationship between gender and the conflict management styles utilized by Arab Muslim immigrants in the United States. While there is extensive literature that explores how 
gender plays a role in different conflict management styles utilized to solve interpersonal conflict, there is great inconsistency in the overall results. Therefore, my findings will support the findings in some studies and contradict those found in others. Interestingly, I found that gender did have a predictive association with utilization of compromising $(\mathrm{p}=0.000)$, avoiding $(\mathrm{p}=0.02)$ and dominating $(\mathrm{p}=0.000)$ conflict management styles. However, there was no predictive relationship between gender and utilization of obliging and integrating conflict management styles.

Again, my findings reinforce some of the results in the literature and contradict others. Haare and Krahe (1999) conducted a study specifically on Indonesians and Germans and found that while culture did have a significant relationship with their choice of conflict management style, gender did not have a significant role in their study. On the other hand, my study did find a predictive relationship between gender and utilization of avoiding and dominating conflict management styles, however, it was in a different study population entirely. Brewer et al. (2002) found that males preferred using dominating styles while female participants tended to use avoidance in the majority of their interpersonal conflicts. While my study doesn't specifically investigate which gender prefers a particular conflict management style, Brewer's study does show that a predictive relationship exists. In addition, Mills and Chusmi (1988) also found that there was a significant relationship between gender and conflict management styles. This is partially supported by my study since such a predictive relationship was found with the utilization of avoiding and dominating conflict management styles. Although there is some literature that explored the role of gender holistically on a macro-level, outside the focus of immigration, there are still many gaps in the literature. My study expanded on the literature by incorporating gender as one of the independent variables on both a macro- and micro-level and assessed whether a relationship existed with the conflict management styles utilized by the Arab Muslim immigrant participants.

One of the possible explanations for my results is that perhaps culture and religiosity play a stronger role in influencing an individual's choice of conflict management style, as was seen in the phase I analysis. Furthermore, participants in this study live in a liberal country that asserts the importance of gender equality, which plays a role in the comfort of individual males and females to use their personal choice in conflict management styles, compared to their counterparts in the Middle East, where gender roles are quite different. Another possible explanation is that males and females may be exposed to different types of conflicts, which may influence the choice of conflict management styles that they choose to utilize in those different situations (Portello \& Long, 1994).

Phase II of the study provided some powerful anecdotal data on the role that gender played as participants chose specific conflict management styles in their workplace (FGM7, FGF6, FGM11). Based on the qualitative data, it appears that it isn't specifically the gender that influenced the conflict management styles utilized, but perhaps the cultural expectations of gender that played a larger role. Specifically, patriarchy is more central to Arab Muslim societal structure compared to United States societal structure where women have greater independence in society and perhaps have greater comfort competing with their counterparts in the workplace.

\subsection{The Role of Religiosity}

Although little research has been conducted to explore the relationship between religiosity and choice of conflict management styles, the studies available give a glimpse of the potential role that religiosity plays when determining conflict management styles utilized in interpersonal conflicts. My study found that religiosity had a significant predictive relationship when it came to choosing obliging $(p=0.001)$, compromising $(p=0.003)$, integrating $(p=0.03)$, and dominating $(p=.000)$ conflict management styles, but had no significant relationship with the avoiding $(p=0.077)$ conflict management style. In addition, first generation immigrants $(74.5 \%)$ demonstrated a higher level of religiosity. Unfortunately, there is a paucity of studies focusing on the role of religiosity in choosing specific conflict management styles. In fact, the only study I could find that investigated this specifically was by Wilson and Power (2004), which found that the level of religiosity does have a predictive relationship with the conflict management styles utilized by individuals. Therefore, since my study did find a predictive relationship with choosing obliging, compromising, integrating and dominating conflict management styles, it supports the study by Wilson and Power (2004).

Other studies investigate specific religions and their influence on conflict management styles. For example, Croucher (2011) found that there was a significant relationship between religion and conflict management styles utilized by (South Asian) Indians. Muslims in his study apparently preferred the integrating and compromising styles, while Hindus preferred the integrating and dominating styles.

It should be noted that phase II of this study did provide useful data in terms of the role of religiosity as a significant factor worthy of investigation. Many interview participants believed that religion played a significant 
role in their daily lives, and they identified themselves as having a high level of religiosity (FGF6, FGF8, FGF9, FGF17, FGM19, and FGM24). Some interview participants who identified with a high level of religiosity felt that their religiosity specifically played a role in how they handled interpersonal conflicts with their colleagues. Perhaps this goes back to the Islamic foundations that encourage prioritizing the groups' goals. Therefore, individuals with a high level of religiosity tended to use a wider variety of conflict management styles.

\section{Study Limitations}

One of the main disadvantages of a mixed method approach is its time and labor-intensive nature. But it allows the researcher to gain a deeper understanding of the research questions at hand. This is because it not only includes the more objective quantitative data, but it is also enriched by the qualitative data. Another limitation in this specific study is the risk of "backyard bias," which is well described by Creswell (2013). Backyard bias occurs when a researcher investigates a population that he or she is a part of. Because the researcher is also Arab and Muslim and an immigrant, his own biases may impact his ability to obtain and report data objectively. Phase I of this study helps overcome such bias because it involves well-studied scales in the survey, allowing the researcher to get unbiased objective data. The second phase of the study was also based on the quantitative results, minimizing the researcher's bias as well. One of the main advantages of knowing the population that is studied is that the researcher knew the population's norms. Specifically, in Islam it is unacceptable for a strange man to be seated alone with a female, as would be the case in the individual face-to-face interviews. To overcome the discomfort that could have occurred with these interviews, the researcher informed potential female interviewees that a female colleague would also be present during the interviews. This made the interviews less tense and made the interviewees more comfortable and likely to be open to discuss the questions at hand.

\section{Conclusion}

As members of the United States workforce, Arab Muslim immigrants make important contributions in their fields. The American workforce has grown increasingly more heterogeneous and diverse. Of course, conflict in the workplace always exists. I focused on the general contributions that gender, culture, and level of religiosity had in influencing the conflict management styles utilized by the study participants.

In this sequential explanatory mixed method study, more weight was given to the quantitative phase compared to the qualitative phase. Nonetheless, both phase I and phase II of the study provided valuable and novel data on the ways in which culture, gender, and religiosity predict the conflict management styles utilized in the workplace by first generation Arab Muslim immigrants in the United States. I found that first-generation immigrants tended to be more collectivistic, have a higher level of religiosity, and utilize a wider variety of conflict management styles.

While this study establishes predictive relationships between gender, culture, and religiosity with at least utilization of some of the conflict management styles, further studies could be conducted to better understand these relationships. Specifically, studies could focus on how each of these factors contributes to conflict management choices of Arab Muslim immigrants in greater detail. Furthermore, studies could investigate how other factors could influence conflict management styles of this population group. Ultimately, additional research is needed on this subject and there is great potential for finding substantive data on the subject.

\section{References}

Abdalla, A. (2001). Principles of Islamic interpersonal conflict intervention: A search within Islam and western literature. Journal of Law and Religion, 15, 151-184.

Ali, A. (1992). Islamic work ethic in Arabia. Journal of Psychology, 126, 507-519.

Alison, J. P. (1975). Three measures of current levels of religiosity. Journal for the Scientific Study of Religion, 14(3), 165-168.

Alzawahreh, A., \& Khasawneh, S. (2011). Conflict management strategies adopted by Jordanian managers based on employees' perceptions: The case for the manufacturing industry. Interdisciplinary Journal of Contemporary Research in Business, 3(7), 147-166.

Bailey, C., White, C., \& Pain, R. (1999). Evaluating qualitative research: Dealing with the tension between science and creativity. Area, 31(2), 169-183.

Bernard, C., Goldstein, J., \& Hazy, J. (2006). Editorial introduction to the Special Issue: From complexity to leadership and back to complexity. Emergence: Complexity and Organization, 8(4).

Bisin, A., \& Verdier, T. (2000). Beyond the melting pot: Cultural transmission, marriage, and the evolution of 
ethnic and religious traits. Quarterly Journal of Economics, 115(3), 955-988.

Blake, R. R., \& Mouton, J. S. (1964). The managerial grid. Houston, TX: Gulf Publishing.

Brewer, N., Mitchell, P., \& Weber, N. (2002). Gender role, organizational status, and conflict management styles. International Journal of Conflict Management, 13(1), 78.

Britto, P., \& Amer, M. M. (2007). An exploration of cultural identity patterns and the Family context among Arab Muslim young Adults in America. Applied Developmental Science, 11(3), 137-150. http://dx.doi.org/10.1080/10888690701454633

Cai, D., \& Fink, E. (2002). Conflict style differences between individualists and collectivists. Communication Monographs, 69, 67-87.

Cetin, M. O., \& Hacifazlioglu, O. (2004). Conflict management styles: A comparative study of university academics and high school teachers. Journal of American Academy of Business, 5(1/2), 325-332.

Chau, E. G., \& Gudykunst, W. B. (1987). Conflict resolution styles in low-and high-context cultures. Communication Research Reports, 4, 32-37.

Chen, J., \& Sheldon, J. P. (2012). Arab-American emerging adults' bicultural identity, acculturation stress, and perceptions of parenting. Journal of Immigrant and Refuge Studies, 10(4), 438-445. http://dx.doi.org/10.1080/15562948.2012.739952

Chiu, K. R., Wong, M. M., \& Kosinski, A. F., Jr. (1998). Confucian values and conflict behavior of Asian managers: A comparison of two countries. Social Behavior and Personality, 26(1), 11-22.

Creswell, J. (2013). Research design: Qualitative, quantitative, and mixed methods Approaches (Ed.). Thousand Oaks, CA: Sage Publications, Inc.

Croucher, S. (2011). Muslim and Christian conflict styles in western Europe. International Journal of Conflict Management, 22(1), 60-74. http://dx.doi.org/10.1108/10444061111103625

Davidhizar, R. (2004). Conflict management styles of Asian and Asian American nurses. Health Care Manager, 23, 46-53.

Dinsmore, P. C. (1984). Human Factors in Project Management. AMACOM-American Management Association. New York.

El-Sayed-Ekhouly, S., \& Buda, R. (1996). Organizational conflict: A comparative analysis of conflict styles across cultures. International Journal of Conflict Management, $7(1), 71$. http://dx.doi.org/10.1108/eb022776

Fitzsimmons, S. R. (2013). Multicultural employees: A framework for understanding how they contribute to organizations. Academy of Management Review, 38(4), 525-549. http://dx.doi.org/10.5465/amr.2011.0234

Fletcher, L., Olekalns, M., \& De Cieri, H. (1998). Cultural differences in conflict resolution: Individualism and collectivism in the Asia-Pacific region. Department of Management Working Paper in Organisation Studies, No. 2. University of Melbourne, Australia.

French, D. C., Pidada, S., Denoma, J., McDonald, K., \& Allison, L. (2005). Reported peer conflicts of children in the United States and Indonesia. Social Development, 14(3), 458-472.

Geertz, C. (1973). The Interpretation of Cultures. New York: Basic Books.

Greenberg, M., Weissberg, R., O’Brien, M., Zins, J., Fredericks, L., Resnik, H., \& Elias, M. (2003). Enhancingschool-based prevention and youth development through coordinated social, emotional, and academic learning. American Psychologist, 58, 466-474. http://dx.doi.org/10.1037/0003-066X.58.6-7.466

Gudykunst, W. B., Guzley, R. M., \& Hammer, M. R. (1996). Designing intercultural training. In D. Landis \& R. S. Bhagat (Eds.), Handbook of Intercultural training (pp. 61-80). Thousand Oaks, CA: Sage.

Haar, B. F., \& Krahe, B. (1999). Strategies for resolving interpersonal conflicts in adolescence: A German-Indonesian comparison. Journal of Cross-Cultural Psychology, 30, 667-684.

He, Z., Zhu, J. H., \& Peng, S. (2001). Cultural values and conflict resolution in enterprises in diverse cultural settings in China. In G. M. Chen and R. Ma (Eds.), Chinese Conflict Management and Resolution (129-148). Ablex, Westport, CT, USA.

Heim, P., Murphy, S., \& Golant, S. K. (2001). In the company of women: Turning workplace conflict into powerful alliances / Pat Heim and Susan Murphy, with Susan K. Golant. New York: J.P. Tarcher/Putnam, 
c2001.

Hofstede, G. (1980). Culture's consequences. Beverly Hills, CA: Sage.

Hofstede, G. (2001). Culture's consequences: Comparing values, behaviors, institutions and organizations across nations. Thousand Oaks, CA: Sage Publications, Inc.

Hofstede, G. (2012). National culture dimensions. Retrieved from http://geert-hofstede.com/national-culture.html

Hofstede, G. J. (1993). Cultural constraints in management theories. In J. T. Wren (Ed.), The leader's companion (pp. 253-270). New York: Free Press.

Hofstede, G., Hofstede, G. J., \& Minkov, M. (2010). Cultures and Organizations: Software of the Mind (3rd ed.). New York: McGraw-Hill.

Huber, S., \& Huber, O. W. (2012). The Centrality of Religiosity Scale (CRS). Religions, 3, 710-724. http://dx.doi.org/10.3390/rel3030710

Hui, C. H., \& Triandis, H. C. (1986). Individualism and collectivism: A study of cross-cultural researchers. Journal of Cross-Cultural Psychology, 17, 225-248.

Jaeger. \& Kanungo, R. N. (1990). Introduction: The need for indigenous management in developing countries. In A. M. Jaeger \& R. N. Kanungo (Eds.), Management in developing countries (pp. 1-19). London: Routledge.

Jordan, J. V. (2001). A relational-cultural model: Healing through mutual empathy. Bulletin of the Menninger Clinic, 65, 92-103.

Kim, T., Wang, C., Kondo, M., \& Kim, T. (2007). Conflict management styles: The differences among the Chinese, Japanese and Koreans. International Journal of Conflict Management, 18(1), 23-41. http://dx.doi.org/10.1108/10444060710759309

Konecki, K. (2004). A private presentation of interactional contexts: Analysis of photographs of pets. A paper presented at the XII Sociological Convention in Poznań.

Kozan, M. K. (2002). Subcultures and conflict management style. Management International Review, 42(1), $89-104$.

Kozan. K. (1989). The influences of individualism-collectivism and self-monitoring on conflict styles. In Avruch, K., Black, P. W., \& Scimecca, J. A. (Eds.), Conflict resolution: Cross-cultural perspectives. Westport, Conn.: Greenwood Press.

LeBaron, M., \& Zumeta, Z. D. (2003). Windows on diversity: Lawyers, culture and mediation practice. Conflict Resolution Quarterly, 20(4), 463-472.

Leung, A. Y., \& Cohen, D. (2011). Within- and between-culture variation: Individual differences and the cultural logics of honor, face, and dignity cultures. Journal of Personality and Social Psychology, 100(3), 507-526. http://dx.doi.org/10.1037/a0022151

Leung, K. (1987). Some determinants of reactions to procedural models for conflict resolution. Journal of Personality and Social Psychology, 53, 898-908.

Lindeman, M., Harakka, T., \& Keltikangas-Järvinen, L. (1997). Age and gender differences in adolescents' reaction to conflict situations: Aggression, prosociality, and withdrawal. Journal of Youth and Adolescence, 26(3), 339-351.

Lulofs, R. S., \& Cahn, D. D. (2000). Conflict: From theory to action (2nd ed.). Boston: Allyn and Bacon.

Markus, H. R., \& Kitayama, S. (1991). Culture and the self: Implications for cognition, emotion, and motivation. Psychological Review, 98, 223-253. http://dx.doi.org/10.1037/0033-295X.98.2.224

Mills, J., \& Chusmir, L. H. (1988). Managerial conflict resolution styles: Work and home differences. In: Goldsmith, E. (Ed.), Work and family: Theory, research, and applications (special issue). Journal of Social Behavior and Personality, 3(4), 303-316.

Morris, J. H., Steers, R. M., \& Koch, J. L. (1979). Influence of organization structure on role conflict and ambiguity for three occupational groupings. Academy of Management Journal, 22, 58-71. http://dx.doi.org/10.2307/255478

Muriithi, N., \& Crawford, L. (2003). Approaches to project management in Africa. International Journal of Project Management, 21(5), 309-319. http://dx.doi.org/10.1016/S0263-7863(02)00048-0 
Nelson, D. T., \& Lubin, B. (1991). Performance of state legislators on the Conflict Mode Instrument. Organizational Development Journal, 9(1), 79-80.

Osisioma, H. E. (2009). Effect of gender, age, and religion on choice of conflict management style in Nigerian organizations. African Journal of Business \& Economic Research, 4(1), 90-105.

Polkinghorn, B., \& Byrne, S. (2001). Between war and peace: An examination of conflict management styles in four conflict zones. International Journal of Conflict Management, 12(1), 23-46.

Portello, J. Y., \& Long, B. C. (1994). Gender role orientation, ethical and interpersonal conflicts, and conflict handling styles of female managers. Sex Roles, 31(11/12), 683-701.

Rahim, M. (2002). Toward a theory of managing organizational conflict. International Journal of Conflict Management, 13(3), 206.

Rahim, M. A. (1983). A measure of styles of handling interpersonal conflict. Academy of Management Journal, 26, 368-376. http://dx.doi.org/10.2307/255985

Rahim, M. A. (2001). Managing Conflict in Organization (3rd ed.). Westport, CT: Praeger.

Rahim, M. A., \& Blum, A. A. (1994). Global perspectives on organizational conflict. Westport, CT: Praeger.

Rahim, M. A., \& Bonoma, T. V. (1979). Managing organizational conflict: A model for diagnosis and intervention. Psychological Reports, 44, 1323-1344.

Randeree, K. (2008). Organizational justice: Migrant worker perceptions in organisations in the United Arab Emirates. Journal of Business Systems, Governance and Ethics, 3(4), 57-67.

Rojahn, K, \& Willemsen, T. M. (1994). The evaluation of effectiveness and likability of gender-role congruent and gender-role incongruent leaders. Sex Roles, 30(1-2), 109-111.

Rowley, S., Hossain, F., \& Barry, P. (2010). Leadership through a gender lens: How cultural environments and theoretical perspective interact with gender. International Journal of Public Administration, 20(2), 81-87.

Ruble, T. L., \& Thomas, K. W. (1976). Support for a two-dimensional model for conflict behavior. Organizational Behavior and Human Performance, 16, 143-155.

Shockley-Zalabak, P. (1981). The effects of sex differences on the preference for utilization of conflict styles of managers in a work setting: An exploratory study. Public Personnel Management Journal, 10, 289-295.

Starks, G. L. (2006). Managing conflict in public organizations: Conflict can be recognized, tackled organizations. Bingley, UK: Emerald Group Publishing Ltd.

Thomas, K. W. (1976). Conflict and conflict management. In M. Dunnette (Ed.), Handbook of industrial psychology (pp. 889-935). Chicago: Rand McNally.

Thomas, K. W., \& Kilmann, R. H. (1978). Comparison of four instruments measuring conflict behavior. Psychological Reports, 42, 1139-1145.

Thomas, K. W., \& Schmidt, W. H. (1976). A survey of managerial interests with respect to conflict. Academy of Management Review, 19(2), 315-318. http://dx.doi.org/10.2307/255781

Ting-Toomey, S. (1988). Intercultural conflict styles: A face-negotiation theory. In Y. Y. Kim, \& W. Gudykunst (Eds.), Theories in intercultural communication (pp. 213-235). Newbury Park, CA: Sage.

Ting-Toomey, S., \& Oetzel, J. G. (2001). Managing intercultural conflict effectively. Thousands Oaks, CA.

Ting-Toomey, S., Yee-Jung, K. K., Shapiro, R. B., Wright, T. J., \& Oetzel, G. (2000). Ethnic/cultural identity salience and conflict styles in four US ethnic groups. International Journal of Intercultural Relations, 24(1), 47-81. http://dx.doi.org/10.1016/S0147-1767(99)00023-1

Tjosvold. \& Wong. (2004). Innovating across cultural boundaries: Applying conflict theory to develop a common approach. International Negotiation, 9(3), 291-313.

Triandis, H. C. (2006). Culture and conflict. In L. A. Samovar, R. E. Porter, \& E. R. McDaniel (Eds.), Intercultural communication: A reader (pp. 22-31). Belmont, CA: Wadsworth.

Trubisky, P., Ting-Toomey, S., \& Lin, S. (1991). The influence of individualism-collectivism and self-monitoring on conflict styles. International Journal of Intercultural Relations, 15(1), 65-84. http://dx.doi.org/10.1016/0147-1767(91)90074-Q

U.S. Census Bureau. (2011). American community survey 3-year estimates (2008-2010) and AAI's research and 
surveys.

Wagner, J. A. (1995). Studies of individualism-collectivism: Effects of cooperation in groups. Academy of Management Journal, 28(1), 152-172. http://dx.doi.org/10.2307/256731

Wilson, R., \& Power, M. R. (2004). Conflict resolution styles among Australian Christians and Muslims. Humanities \& Social Sciences Papers, 7.

\section{Copyrights}

Copyright for this article is retained by the author(s), with first publication rights granted to the journal.

This is an open-access article distributed under the terms and conditions of the Creative Commons Attribution license (http://creativecommons.org/licenses/by/3.0/). 